

\title{
The Influence of Religion on Philanthropy in Canada ${ }^{1}$
}

\begin{abstract}
Recognition of the multi-cultural nature of the Canadian population has led companies across a wide array of business domains to reach beyond their traditional bases of support to focus on hitherto untapped communities as potential markets for their goods and services. Competitive conditions within the voluntary sector have pushed non-profits along this same path. However, no systematic Canadian research reports on the attitudes, social norms, benefits sought, expectations, opportunities, experiences, or behaviors of sub-communities in the voluntary sector. This paper examines philanthropic behavior by religion using data from the Statistics Canada 2000 National Survey of Giving, Volunteering and Participating (NSGVP). The paper compares and contrasts the voluntary and philanthropic behaviors of the Canadian population across religious groups; compares and contrasts the motivations for and perceived impediments against such behaviors; and articulates and examines a model that traces the influence of religion on voluntary and philanthropic behavior in Canada's multicultural society.
\end{abstract}

\section{Introduction}

The last two decades have seen substantial growth in the voluntary sector, accompanied by significant reductions in government resources supporting the sector's activities (Browne, 1996). This confluence of sector growth and decreased governmental support has resulted in increased competition among voluntary organizations for both capital and human resources (Meinhard \& Foster, 2003; Stroschein, 2002). Furthermore, recognition of the multi-cultural nature of the Canadian population has led many in the voluntary sector to consider the impact of cultural diversity on the philanthropic behavior of Canadians (Husbands, McKechnie, \& Gagnon, 1999). Coupled with the availability and success of "target-marketing" in the private sector, these forces have pushed many voluntary organizations to explore more segmented recruitment approaches. However, targeting specific sub-populations in order to expand sources of support is neither easy nor straightforward. Recruitment strategists must recognize that different population groups function within different sets of beliefs about and attitudes toward philanthropy; experience different normative pressures; and face different levels of inclusion and accessibility.

Using data from the Statistics Canada 2000 National Survey of Giving, Volunteering and Participating (NSGVP), this paper examines the systematic variance in Canadian philanthropy based on religious affiliation by exploring both self-determined factors (i.e. personal attitudes) and socially determined factors (norms and social exclusion). Specifically, the research 1) compares and contrasts the voluntary and philanthropic behaviors of the Canadian population across religious groups; 2) compares and contrasts the motivations for and perceived impediments against such action; and by so doing, 3) articulates and examines a model that traces the influence of sub-group status on voluntary and philanthropic behavior in Canada's multicultural society. 


\section{Conceptual Development}

As a multi-cultural country where diversity is celebrated and immigration a constant reality, Canada is composed of a growing number of citizens who define themselves as both Canadians and members of sub-cultures. Marketers across a wide array of organizations, from nationally marketed packaged-goods firms to politicians and government departments, are recognizing that mass, un-segmented strategies that ignore population distinctions are no longer effective. Indeed, voluntary sector research on age, gender, race, and religious activities (see, e.g., Goss 1999; Cnaan, Kasternakis, \& Wineburg, 1993) has been very illuminating. In particular, Reed and Selbee (2001), using the 1997 and 2000 NSGVP, demonstrated the importance of religion and religiosity in discriminating between those who are and those who are not civically active. However, the implications of religious diversity on attitudes, norms, and social facilitators or impediments regarding philanthropy in Canada have not been explicitly addressed.

Consistent with recent work investigating the role of human, cultural, and social resources in explaining race-based (Musick, Wilson, \& Bynum, 2000), gender-based (Schlozman, Burns, \& Verba, 1994) and religion-based (Cnaan, Kasternakis, \& Wineburg, 1993) differences in philanthropy, this study will examine differences in attitudes, norms, experiences, and philanthropic behaviors (both the giving of time and money) across religious subpopulations. In this analysis, I take the position that identity influences the nature of attitudes toward and perceived normative pressures regarding philanthropic behavior. Whether one is - or chooses to see oneself as - a Canadian-Jew or an un-hyphenated Canadian, for instance, affects cognitive, affective, and social antecedents of giving and volunteering. In addition, whether one is seen to be - or considered by others to be - a member of a particular religious sub-group influences the existence of factors that serve to either facilitate or impede philanthropic activity. For instance, being identified as a member of one religious group may increase the number of personal invitations to volunteer, increasing one's knowledge about where and how to volunteer, and thereby facilitating the volunteering decision. Being identified as a member of another group, or having no affiliation at all, may curtail the number of invitations received and may thereby impede the volunteering decision. I suggest that it is through this mediated process that sub-group affiliation influences philanthropic behavior.

Attitudinal influences A large literature now exists examining "cultural asymmetry" in preference and persuasion, implying that different behaviors are consistent with different cultural meanings (see Aaker, 2000, for a review) Marketing researchers examining the culturally distinct effects of different promotional appeals have found, for example, that North Americans are more responsive to messages associated with self-reliance, self-improvement, and the achievement of personal goals. In contrast, Koreans are more responsive to messages focused on family integrity, collective goals, and feelings of harmony with others (Aaker, 2000). These asymmetric results have been explained as stemming from two cognitive processes. First, because of diversity in culturally based traditions, religions, and histories, different cultures hold culturally distinct sets of values and beliefs. Secondly, culturally distinct media, personal experiences, or social environments render culturally distinct beliefs more accessible. Both explanations suggest that predispositions to objects or actions are based on culturally distinct sets of beliefs, and are evaluated according to culturally distinct criteria. In the context of philanthropic behavior, the 
culturally asymmetric findings imply that the specific beliefs associated with giving, the way such beliefs are evaluated, and consequently the attitudes toward giving behavior in general and towards giving to specific organizations in particular, may vary by sub-group affiliation. Thus, the decision to give, and where, will be based on the sub-group socialized meanings ascribed to the behavior and therefore will vary by sub-group affiliation.

Normative influences In addition to personal, within-individual factors, philanthropic behavior may also be influenced by the norms and obligations of an individual's social network. The features of social organization that facilitate cooperation and collaboration for mutual benefit are referred to as "social capital" (Putnam, 1995). Social capital exists within and through structures of relationships that are based on norms of reciprocity, collective interest, individual obligation, and trustworthiness (Portes, 1998; Coleman, 1988). Portes (1998) recently presented a framework suggesting that individual identification with a group, recognition of a common fate, and feelings of "bounded solidarity" represent the antecedent sources of social capital. He argued that it is these feelings of solidarity that motivate strongly identified, wealthy members of a community to give to the network, and give needy members of the community access to the benefits made possible by the network.

The application of this model is straightforward here. Higher levels of culturally distinct identification (bounded solidarity) should lead to a stronger network of culturally distinct relationships (increased social capital) that in turn lead to higher levels of culturally distinct voluntary behavior (resources provided and available in the network). This implies that those with strong culturally distinct identities will be embedded in social networks dominated by referents with similar identities. Subjective norms in such a network would direct members to contribute resources (both time and money) to the culturally distinct activities that are valued by the network (see Berger \& Gainer, 2000 for support for this conceptualization in the U.S. Jewish community). Thus, the decision to give, and where, will depend on the extent to which the behavior supports, and is supported by, an individual's chosen social network, and therefore will vary by sub-group affiliation.

Facilitating/impeding factors Diversity, including religious diversity, has been a mainstay in profiles of the Canadian population. Liberal immigration policies have resulted in a large proportion of citizens with ancestries other than the founding peoples (First Nations, English Protestants, and French Catholics). While this diversity adds immeasurably to the richness of Canadian culture, it also challenges Canadians to continually examine the accessibility, inclusiveness and equity of their institutions and processes. As a nation Canadians point regularly to their unique ability to integrate but still support diversity; yet, there is evidence of social barriers faced by ethnic, religious, and visible minorities from as far back as World War I.(Walker, 1989).

In the voluntary domain, discrimination may take the form of social barriers that result in some groups not being actively solicited, not being made aware of philanthropic opportunities or benefits, or not being approached or treated in a culturally sensitive manner. If members of some sub-groups are systematically "outside" the mainstream voluntary sector, either because of their own attitudes or group norms, or because of externally imposed social barriers, then they are excluded from the very processes through which their social and economic status might improve, 
and the processes through which they might integrate and contribute fully to Canadian society.

It is the purpose of this paper to examine whether or not there are systematic differences in philanthropic participation by religious affiliation. In addition, I explore whether such differences stem from personal altruistic motivations (attitudes), from religious group norms, or from social barriers. Directional hypotheses are diagramed in Figure 1. Based on research in the sociology of religion, social capital and the voluntary sector (Hoge et al., 1996; Portes, 1998; J. Berger, 2003), I expect there to be differences in behavior based on religious identity. Based on well documented, frequently replicated research outside Canada, I expect that members of more evangelical, fundamentalist, religiously demanding Christian religious groups, such as conservative Protestants will demonstrate higher levels of philanthropic engagement than more liberal Christian groups such as Catholics. (In particular see Hoge et. al. 1996). Further, I expect these differences to vary systematically with differences in attitudes, group norms, and social barriers. In general, attitudes and group norms that favor philanthropy are expected to exert a positive influence on individual philanthropic behavior. Social barriers, by contrast, are expected to exert a negative influence on philanthropy. However, it is unknown how philanthropic behavior and these mediating variables will vary across non-Christian groups. In other words, considering a broad set of religious groups it is not known, and cannot be hypothesized a priori, which religious groups will have more positive attitudes or group norms, which groups will face greater social barriers and how exactly philanthropy will vary. It is the purpose of this study to investigate these specific questions.

\section{Method}

Using data from the Statistics Canada 2000 National Survey of Giving, Volunteering and Participating (NSGVP), the study seeks to compare and contrast attitudes, norms, barriers, and philanthropic behaviors by religious affiliation. The NSGVP is "the most comprehensive assessment of giving, volunteering and participating ever undertaken in Canada, and perhaps the world" (Hall, McKeown, \& Roberts, 2001, p. 5). It represents a dataset that captures the giving, volunteering and participating behaviors, attitudes and perceptions of 14,724 Canadians. The dataset includes not only questions about behaviors per se (such as amount given or hours volunteered), but also specifics in terms of organizations given to or volunteered with, and includes reasons for the behaviors (i.e., motivations) and impediments to the behaviors (e.g., not being asked). For this study, the data were obtained and analyzed through the Research Data Centre at the University of Toronto. Four sets of questions were used in this analysis.

First, sub-group identity was captured in terms of Religious Affiliation and was measured on the basis of the question "What, if any is your religious affiliation?" Nineteen religious affiliations were recorded, as well as "No religious affiliation." Following Hoge, et al. (1996), Beyer (1997) and others, these 20 groups were further grouped as follows: conservative Protestant (Baptist, Pentecostal, Jehovah's Witness, and Protestant Other), liberal Protestant (Anglican, United, Presbyterian, and Lutheran), Roman Catholic, Other Catholic (Ukrainian, Eastern Orthodox, other Catholic), Jewish, Eastern (Islam, Sikh, Hindu, Buddhist), Other religion and No religious affiliation Within the Eastern categorization, 36\% of respondents were Moslem, 16\% were Sikh, 28\% were Hindu and 20\% were Buddhist. 
The second set of questions asked about philanthropic behavior in the previous year. Respondents were asked to specify the dollar amounts of donations made, the manner of giving, and the nature of the organizations and activities supported. All contributions, by household, were summed (by Statistics Canada) to provide a Total Dollars Donated per Household figure as well as a Total Dollars given to Religious Organizations figure. Individuals who claimed to make no donations were coded as having donated $\$ 0$." Similarly, respondents were asked to specify the number of hours volunteered, the type of activities performed, and the organizations for which they volunteered, over the preceding year. Statistics Canada again provided a Total Hours Volunteered per Year figure, as well as a Total Religious Hours Volunteered. Individuals who claimed to do no volunteering were coded as having volunteered "0 hours."

Thirdly, beliefs, motivations, and barriers were measured using four series of questions regarding reasons for giving or volunteering and reasons constraining giving (more) or volunteering (more). All questions were simply recorded as a "yes," "no," or "no answer." The sets of reasons for giving included "the government gives a tax credit, compassion, religious beliefs, personal beliefs, owe something to the community, was personally affected." Reasons for not giving included "can't find a good cause, want to save money, don't know where to give, money will not be well used, prefer to spend money in other ways, volunteer instead, already contribute enough, don't like the way money is solicited." The reasons for volunteering included "personally believing in the cause, having been personally affected, having friends who volunteer, to find job opportunities, because of religious beliefs, to explore personal strengths, to make use of my skills." The reasons for not volunteering were "already contribute, don't have time, have health problems, no one I know asked me, don't know how, too high a financial cost, might get sued, not interested, give money instead, can't make a year-long commitment, dissatisfaction with previous experience." Responses to these questions were factor analyzed in order to reduce the number of mediating variables to a more manageable figure. Principle Components Analysis, with Varimax rotation, using an Eigen value cutoff of 1 was the method used in all cases. The final factor patterns with their associated statistics are displayed in Tables I through IV. Factor analyses resulted in the emergence of two reasons- forgiving factors, labeled as "personal altruism and social norms"; three reasons-for-not-giving factors, labeled as "personal discontent, competing demands, and social barriers"; three reasonsfor- volunteering factors, labeled as "personal benefits, personal altruism, and social norms"; and four reasons-for-not-volunteering factors, labeled as "time demands, personal costs, social barriers and other competing factors."

Finally, two questions were used to estimate an individual's "religious commitment." Respondents were asked to indicate on a 4-point scale that ranged from "Not at all" to "At least once a week how often they had attended religious services or meetings in the past twelve months - not including funerals, weddings, or other special events -." In addition, respondents were asked to categorize their own religiosity from "Not at all religious" to "Very religious." The mean value of these two questions was used to represent religious commitment.

<Insert Tables I through IV here (to be found after the References)> 
Data were analyzed using cross-tabulations and linear regression procedures in SPSS. Statistics Canada has stringent confidentiality and disclosure regulations that require that all analyses be conducted and reported on weighted samples only. This policy is strictly monitored and enforced with analyses carefully examined and vetted by Statistics Canada's technical staff in order to ensure accuracy, confidentiality and generalizability. The weight used for all analyses in this study is the general weighting factor representing the survey's sampling frame as supplied by Statistics Canada, effectively turning this into a population of 22+ million adults over the age of 15 . Thus, all differences and all statistical tests are statistically significant at pvalues well below commonly accepted levels. In this circumstance the challenge facing the researcher is not to determine the probability that an observation is genuine, as opposed to a chance occurrence, but rather to identify and interpret observations of theoretical and/or practical interest. In the following discussion, differences or findings that represent practically substantive variance are highlighted.

\section{Results}

\section{Giving and Volunteering By Religious Affiliation}

Table $\mathrm{V}$ displays the total dollars, percentage of household income, total giving to religion, and method of giving by those classified as affiliated with seven religions and those who are non- affiliated. Table VI shows the average hours volunteered annually, percentage of available hours volunteered (therefore accounting for employment status), average hours volunteered to religion, and the kinds of activities performed by the eight religious sub-groups. On all measures, those classified as non-religiously affiliated give less than the rest of the population. The un-affiliated give significantly fewer dollars, give a significantly smaller proportion of total income and are significantly less likely to give via virtually all giving methods. Similarly, the non-affiliated volunteer at levels below average for virtually all kinds of activities.

\section{<Insert Table V here>}

Tables V and VI also establish substantive variance in giving and volunteering across religious denominations. On virtually all measures, with or without "economic" corrections, conservative Protestants give more dollars, give a larger proportion of total income, volunteer more hours and volunteer for a larger proportion of their available hours. Moreover, conservative Protestants are more likely to give through all giving methods, and are more likely to volunteer for all kinds of activities. Particularly interesting is the fact that almost $60 \%$ of conservative Protestants give through their church collections, with fully $75 \%$ of their giving going to religious causes, while those measures are only $40 \%$ and $46 \%$, respectively, on average for other religions. In addition, nearly $20 \%$ of conservative Protestants - compared to about half that figure of non-Protestants - are involved voluntarily in fundraising, board memberships, and other critical organizational activities, again predominantly with religious organizations. These results present a picture of conservative Protestants as deeply involved and heavily committed both financially and through active participation - to the voluntary sector, particularly the religious segment of the sector. Within the Christian sector these results are neither surprising 
nor new, however, the relative position of the Jewish and Eastern affiliations, and the behavior of those not religiously affiliated has not been previously described. Given the size of the nonaffiliated group (26\% of the population), and the rapid growth rate of the Eastern group through immigration, understanding these results is important to voluntary sector fund raisers and recruiters.

\section{<Insert Table VI here>}

Within the overall framework of this research, the evidence clearly shows that religious affiliation is an important determinant of Canadian philanthropy. Those not affiliated with any religion, and those who are members of Catholic or Eastern denominations, give and volunteer less than members of other denominations, and thus represent a relatively untapped and significant pool of potential donors and volunteers. To take advantage of this opportunity, the model outlined above suggests an examination of how group-specific attitudes, norms, and social barriers might mediate the process through which religious affiliation influences philanthropy.

\section{Mediating Factors by Religious Affiliation}

Tables VII and VIII display mean factor scores by religious affiliation on the attitudinal and social variables proposed to mediate giving and volunteering behavior. Recall that two reasons- for- giving factors were identified ("personal altruism and social norms"); three reasons-for-not-giving factors were identified ("personal discontent, competing demands, and social barriers"); three reasons-for-volunteering factors were identified ("personal benefits, personal altruism, and social norms"; and four reasons-for-not-volunteering factors were identified ("time demands, personal costs, social barriers and other competing factors"). The scores in Tables VII and VIII can range from a high of one $(+1)$ to a low of minus one (-1), with scores near zero (0) representing the sample mean. Of particular interest are questions that clearly distinguish the non-affiliated from the affiliated, and that distinguish the conservative Protestants from everyone else. Obviously, the non- affiliated feel little religious motivation to give or volunteer. This is evident in their very low scores on the giving social norms factor (last column of Table VII) and the volunteering altruism factor (last column of Table VIII), both of which include the religious motivation item. However, the non- affiliated group differs very little from other groups on motivating factors covering tax relief and other personal benefits, for instance. These responses do not imply less generosity per se - in other words, less supportive attitudes toward philanthropy - but perhaps relatively less contact or personal experience with the voluntary sector. Being unaffiliated religiously may mean being unaffiliated in general. Members of this group may be highly self-motivated and possibly generous when they feel a real personal connection to a cause, but appear to be invisible otherwise. Since they are unlikely to appear on any available "list," the recruitment challenge is to find, contact and connect with these individuals on a one-to-one basis. The results suggest the need to provide opportunities to give, more than reasons to give.

\section{$<$ Insert Tables VII and VIII here>}

The responses of conservative Protestants regarding their reasons for philanthropy stand in stark contrast to those of the non-affiliated. Their very high level of giving and volunteering is heavily motivated by their feelings of altruism (.13 in Table VII and .35 in Table VIII) and 
perceived social (in this case religious) obligations (.36 in Table VII). The Jewish community also stands out in the importance of both personal attitudinal factors and group norms of giving. Importantly, for this community, group norms support general communal giving, as opposed to religious giving. This is demonstrated by the high score on the giving social norms factor $(.35$ in Table VII) which includes both communal and religious obligations, and the low score on the volunteering altruism factor which includes the religious motivation item (.08 in Table VIII). Also worth noting is the fact that $72 \%$ of Jewish giving is directed toward non-religious causes (see Table V), which makes the Jewish group the highest givers in the non-religious domain. The behavior of both of these very philanthropic denominational groups seems to depend on strongly positive personal attitudes coupled with strong norms of group obligation and reciprocity. Both Protestants and Jews appear to experience many of the same de-motivators as the rest of the population - personal discontent or time demands - yet both seem able to set them aside. The combination of communal obligation and positive personal motivation appears able to overcome the negative factors and drive the philanthropy of members of these groups to an extent that the factors cannot achieve individually. The results imply that by increasing donors' personal feelings of responsibility, obligation and solidarity to the group or cause - whether religious or secular - voluntary organizations could potentially increase donor support. This is consistent with studies of altruism that suggest that communal engagement depends upon "a frame of mind by which people think of themselves as members of a common world" (Clohesy, 2000, p. 248).

Also noteworthy in these tables are the high scores of the Eastern group on experienced social norms of giving (.56 in Table VII and .18 in Table VIII) that are apparently curtailed by substantial social barriers (.62 in Table VII and .69 in Table VIII). While members of this group appear to feel substantial social obligations to give and volunteer, they indicate a lack of awareness of where to give, and claim not to be personally solicited to volunteer. This comes as no real surprise, as this group represents the most recent immigrants to Canada (Statistics Canada, 2003), a high proportion of whom are members of visible minorities with relatively low socio-economic status. Given the importance noted above of feelings of community obligation, personal connection and solidarity, finding mechanisms of access, persuasion, and inclusion for this religious group may be a fruitful avenue of increasing support. Once again, focal attention might be better placed on the provision of giving opportunities, and enhancing the ability to give, rather than reasons to give.

Thus the results portrayed in Tables VII and VIII provide further support for the framework advanced in this research. It can be seen from the factor scores that members of religious denominations differ systematically not only in their philanthropic behavior (as evident in Tables $\mathrm{V}$ and $\mathrm{VI}$ ), but also in the hypothesized mediating reasons for their philanthropy. In particular, the results indicate that members of religious denominations differ in the attitudes they hold, the group norms they perceive, and the social barriers they experience. It remains to examine through regression modeling whether these variations do indeed mediate the influence of religious affiliation on philanthropy. 


\section{Investigating the Mediation Model}

In order to examine whether the motivating factors mediate and thereby explain the religious- group differences in reported amounts and rates of philanthropy, Baron and Kenny's (1986) analytic framework was used. Baron and Kenny showed that mediation exists when it can be shown that the demonstrated influence of an independent variable on a dependent variable is reduced - reduced to non-significance for complete mediation - once the effect of a mediating variable is accounted for. To demonstrate mediation, three things must be shown. First, it must be demonstrated that there is a significant relationship between the antecedent variable (religious affiliation, in this case) and the target dependent variable (giving or volunteering). Second, there must be a relationship between the antecedent variable and the proposed mediators (in this case, between religious affiliation and reasons for giving or volunteering, or for not doing so). Third, it must be shown that when the influence of the mediators is accounted for, the influence of the antecedent variable on the target dependent variable is substantially reduced. Thus, mediation can be tested by examining four (conceptual) regression equations for each behavior: regressing giving (or volunteering) on religious affiliation; regressing the motivating factors on religious affiliation; regressing the demotivating factors on religious affiliation; and regressing giving (or volunteering) on the motivating factors, de- motivating factors and religious affiliation. Because household income (or available hours) represents a significant "other" variable that needs to be accounted for in any explanation of philanthropy, income (or available hours) is included in all models of giving (or volunteering). Tables IX and $\mathrm{X}$ report the results of the relevant regression analyses for giving and volunteering, respectively.

\section{<Insert Tables IX and X here>}

As with social-psychological experimental research using ANOVA, or other questions involving multiple, inter-related antecedents (Berger, 1999) the goal in this analysis is not 'prediction' in the sense of presenting a model that maximizes explained variance. Rather, the intention is to examine whether or not religiously based variance in giving and volunteering functions through the mediating processes hypothesized. In other words, the magnitude of an equation's $\mathrm{R}^{2}$ is not, in this case, the relevant criteria. At issue is the change in Beta coefficient and t- value as each subsequent variable is added to the equation (Baron \& Kenny, 1986).

The first six columns of Table IX replicate the descriptive results observed in Tables V and VII. Each of the affiliation variables was coded as 1 for the stated religion and 0 otherwise, all regressions were run using the non-affiliated as the omitted comparison group, and factor scores were used to represent the mediating motivations. Regression 1, indicates a significant influence of religious affiliation on total amount given with the strongest effect evident for the conservative Protestants. Furthermore, Regressions $2 a$ and $2 b$ indicate the strong influence of Protestant affiliation on feelings of altruism and social norms. In addition, Regression 3c indicates the strong influence of Eastern religion on the indicator of social barriers. Further, the drop in the magnitudes of the Beta coefficients (and t-values) for the liberal Protestant, conservative Protestant, Jewish, and Eastern religion variables - once the mediating factors are included in the regression model (Regression 4a) - provides support for the mediating process hypothesized. In the model depicted in Regression $4 \mathrm{a}$, it is important to note the strong positive influence of the normative factor, and the strong negative influence of the social barriers factor. 
Once again the results suggest that by increasing feelings of communal responsibility and group norms, and by increasing feelings of inclusion through information and personal solicitation, support for the voluntary sector could be substantially increased.

Regression $4 \mathrm{~b}$ adds religiosity to the model, providing further insight into the influence of religion. As can be seen from the magnitude of the religiosity Beta coefficient (.14), being more religious (in terms of self-identity and attendance at services) adds significantly to the amount contributed to charity. Furthermore, the drop in the coefficient on virtually all of the religious- affiliation indicators suggests that a significant proportion of the variance in giving by religion can be accounted for by variance in religiosity. In other words, it would be incorrect to conclude that Protestant religious dogma is necessarily more charitable than Catholic dogma; rather, it appears that because Protestants are more likely to incorporate their religious obligations and teachings more broadly into their life and behavior, they give more. The negative coefficient on some of the affiliation variables - once religiosity is accounted for - in Regression $4 \mathrm{~b}$ implies that members of these religions (Catholics, Jews, Eastern) see themselves as less religious than some of the others (Protestants, Other). Analysis of the religiosity variable by religious affiliation confirms this interpretation. Were (lapsed) Catholics, for example, to reaffirm their religious identities and begin to attend religious services more frequently, the results of this analysis suggest that much higher levels of Catholic giving would ensue.

As with giving, the results on volunteering - Regressions 1, 2, and 3 (columns 1 to 8) of Table $\mathrm{X}$ - replicate the findings earlier discussed. Once again, feelings of altruism (Regression 2b) are largely (though not exclusively) associated with the large volunteering groups such as the Protestant groups, and feelings of social barriers are associated with the Eastern religious group (Regression 3c). Importantly, for volunteering, the importance of personal benefits (Regression 2a) as reasons for volunteering for some groups is clearly evident. In addition, in the full regressions the strong positive influence of offering personal benefits, and the high cost of demanding too much time or not making personal solicitations are also evident. And finally, once again, the importance of religiosity in explaining religious variance in volunteering can be seen. Thus, analyses of the volunteering data imply that in positioning and marketing volunteer opportunities, organizations should highlight the skills and experiences gained by volunteers (i.e., benefits offered), should not demand too much time or effort initially (i.e., long-term commitments), and should attempt to make personal connections with potential volunteers. These tactics are likely to be effective with potential donors who do not see themselves as particularly religious.

The results overall are supportive of the model hypothesized in Figure 1. Religious affiliation is strongly related to philanthropic giving of money and time. This relationship can be explained in terms of religion's influence on important mediating variables. In particular, religious affiliation is shown to have an impact on attitudes, perceived social norms, and experienced social barriers toward philanthropy. Furthermore, the mediated regression findings suggest that the underlying reasons for sub-group variance in behavior are predominantly normative and structural. Those who give, give to fulfill the obligations (social, communal, or religious) of their chosen social network. Those who do not give are either not exposed to or do not perceive the social facilitators in place (such as tax incentives or employment opportunities). Alternatively, or in addition, those who do not give may be excluded implicitly - or perhaps explicitly - from donor- and volunteer-recruitment campaigns. 
Also noteworthy are the results regarding religiosity, which in this analysis represented more than a state of mind. An individual's self-categorization as 'religious', coupled with frequent attendance at religious services and meetings, is strongly related to both giving and volunteering, even after denominational affiliation is accounted for. While it has been argued elsewhere that certain religions are more likely to encourage donation and voluntary behavior (J. Berger, 2003) this result implies that differences in beliefs and behavior within religious groups are also important. Furthermore, the religiosity measure captures the strength of both the psychological motivation and the behavioral opportunity offered by religion to participate in some way in the voluntary sector. While nonreligious voluntary organizations may not be able to, nor in fact need to, replicate the motivational factor, they may find it advantageous to replicate the opportunity factor. Recall for instance that the non-affiliated group had the lowest levels of giving and volunteering, despite average levels of personal altruism. Consequently, it may be important to explore strategies designed to increase not just motivations, but also opportunities to give and volunteer, both within and outside religious communities. Such strategies might focus on social network strategies that facilitate and strengthen contact, interaction and commitment within and between social groups (Stroschein, 2002).

\section{Conclusions}

Using data from the 2000 National Survey of Giving, Volunteering and Participating, this paper explored the influence of identity in the form of religious affiliation on giving and volunteering among Canadians. The results indicate that even when differences in income and available hours are accounted for, there is substantial variance in dollars and hours given to the voluntary sector based on sub-group identification. Religious affiliation and self-perceived religiosity appear to be important as influences on philanthropic variance. Those who are nonreligiously affiliated are the least philanthropic, while those who identify themselves as conservative Protestants are the most philanthropic. Using both descriptive and multivariate methods, these findings were explained in terms of an absence of feelings of communal responsibility or reciprocity on the part of the non-affiliated and the existence of significant social barriers for the newest Canadians. Secondly, the very high levels of giving on the part of some groups (particularly conservative Protestants to religious causes, and Jews to secular causes) were also traced to the influence of these same factors - in their case the existence of very strong positive social norms coupled with the existence of social-structural facilitators.

At a theoretical level, the results provide considerable support for both the general mediational framework underlying this investigation and the specific hypotheses proposed. It does appear that social identity is an important determinant of philanthropy. Furthermore, the influence of this focal variable can be usefully understood in terms of its influence on three sets of mediating variables: personal attitudes, social norms, and socio-cultural structure. Some might in fact characterize these as three different levels of analysis. The personal attitudes represent micro-issues of psychology and personal, internal causes. The social norms represent mesoissues of sociology, network, or group influence. The social barriers represent more macroquestions of social organization, cultural interaction, and inclusion and exclusion. Not surprisingly, a full understanding of giving and volunteering calls for attention and modeling at 
all three levels of analysis. The model articulated and tested herein provides a first step in this regard.

At a practitioner level, the results suggest fruitful avenues for voluntary organizations interested in attracting more donations and more volunteers. The differential giving patterns and the differential mediating variables support the validity of focused, targeted recruitment strategies. Members of different religious groups systematically give differently, give for different reasons, and face different giving barriers. Mass, "one-size fits all" recruitment or management strategies are unlikely to be the most effective. Rather, recruiters should identify behaviorally relevant bases of segmentation and develop communication, training, and management methods targeted at the most promising segments. This research suggests that religious affiliation may be a very fruitful segmentation criterion. Furthermore, the results suggest that for those citizens who are not yet significant givers focusing on communal connections, personal appeals and the promise of personal benefits may represent avenues to pursue. Within a segmented strategy, this would mean understanding the bases of community and the particular appeals and benefits sought by focal groups, and then developing ways to leverage group-specific predispositions that support philanthropy, while overcoming groupspecific barriers to philanthropy.

Clearly, this analysis is only suggestive and exploratory. Not all - and perhaps not even the most important - reasons for giving or volunteering were examined here. The investigation was constrained by the data that were collected. Furthermore, the underlying motivations and barriers identified are very general, and not nearly specific enough for normative, operational conclusions. What the study does point to is the great potential from both research and managerial perspectives of examining philanthropic behavior with a disaggregated, multi-level lens. Clearly religious affiliation is not the only sub-group identifier that might be related to philanthropic behavior. Ethnicity, race, visible minority status, place of birth and perhaps others are all potential sources of systematic variance that could be traced to the mediating factors herein examined. The voluntary sector would greatly benefit from more research, particularly rich qualitative research, in this regard. 


\section{References}

Aaker, Jennifer L. (2000). Accessibility or Diagnosticity? Disentangling the Influence of Culture on Persuasion Processes and Attitudes. Journal of Consumer Research, 26 (March), 340-357.

Baron, Reuben M., \& Kenny, David A. (1986). The Moderator-Mediator Variable Distinction in Social Psychological Research: Conceptual, Strategic, and Statistical Considerations. Journal of Personality and Social Psychology, 51 (6), 1173-1182.

Berger, Ida E. (1999). The Influence of Advertising Frequency on Attitude-Behavior Consistency: A Memory Based Analysis. Journal of Social Behavior and Personality, 14 (4), $547-$ 568.

Berger, Ida E. \& Gainer, Brenda (2000). Identity, Communal Embeddedness and Philanthropy. Paper presented at the Fourth International Conference of the International Society for Third Sector Research, Dublin, Ireland.

Berger, Julia (2003). Religious Nongovernmental Organizations: An Exploratory Analysis. Voluntas, 14 (1), 15-39.

Beyer, Peter (1997). Religious Vitality in Canada: The Complementarity of Religious Market and Secularization Perspectives. Journal for the Scientific Study of Religion, 36 (2), 272-288.

Browne, Paul L. (1996). Love in a Cold World? The Voluntary Sector in the Age of Cuts. Ottawa: Canadian Centre for Policy Alternatives.

Clohesy William, W. (2000). Altruism and the Endurance of the Good. Voluntas, 11 (3), 237-253.

Cnaan, R., Kasternakis, A., \& Wineburg, R.J. (1993). Religious people, religious congregations, and volunteerism in human services: Is there a link? Nonprofit and Voluntary Sector Quarterly, 22 (1), 33-51.

Coleman, James (1988). Social Capital in the Creation of Human Capital, American Journal of Sociology, 94 (Supplement), S95-S120.

de Silva, Arnold \& Doherty, Craig (1996). Discrimination Against Visible Minority Men. Ottawa: Applied Research Branch, Strategic Policy Human Resources, Development Canada.

Goss, Kristin A. (1999). Volunteering and the Long Civic Generation, Nonprofit and Voluntary Sector Quarterly, 28 (4), 378-415.

Hall, Michael, McKeown, Larry, \& Roberts, Karen (2001). Caring Canadians, Involved Canadians: Highlights from the 2000 National Survey of Giving, Volunteering and Participating. Ottawa: Minister of Industry, Catalogue no. 71-542-XPE.

Husbands, Winston, McKechnie, A.-J., \& Gagnon, Mario (1999). An Assessment of the Need to Improve the Body of Knowledge on Volunteers and Volunteering in Canada. Toronto: Canadian Centre for Philanthropy.

Hoge, Dean R., Zech, Charles E., McNamara, Patrick H., \& Donahue, Michael J. (1996). Money Matters: Personal Giving in American Churches. Louisville, Kentucky: Westminster John Knox Press.

Meinhard, A.G. \& Foster, M. K. (2003). Differences in the response of women's voluntary organizations to shifts in Canadian public policy, Nonprofit and Voluntary Sector Quarterly, 32 (3), 366-396.

Musick, Marc A., Wilson, John, \& Bynum, William B. (2000). Race and Formal Volunteering: The Differential Effects of Class and Religion, Social Forces, 78 (4), 1539-1571.

Portes, Alejandro (1998). Social Capital: Its Origins and Applications in Modern Sociology. Annual Review of Sociology, 24, 1-24. 
Putnam, Robert D. (1995). Bowling Alone: America's Declining Social Capital. Journal of Democracy, (January), 65-78.

Reed, Paul B. \& Selbee, L. Kevin (2001). The Civic Core: Disproportionality in Charitable Giving, Volunteering, and Civic Participation. Nonprofit and Voluntary Sector Quarterly, 30 (4), 761-780.

Schlozman, Kay L., Burns, Nancy, \& Verba, Sidney (1994). Gender and the Pathways to Participation: The Role of Resources. The Journal of Politics, 56 (4), 963-90.

Statistics Canada (2003). Social Trends in Canada: Focus on Toronto. Seminar, September 4. Stroschein, Sherrill (2002). NGO Strategies for Hungarian and Roma Minorities in Central Europe. Voluntas, 13 (1), 1-26.

Walker, James W. St.G. (1989). Race and Recruitment in World War I: Enlistment of Visible Minorities in the Canadian Expeditionary Force. Canadian Historical Review, LLX (1). 
Table I: Final Factor Pattern

Reasons for Giving: Rotated Component Matrix

\begin{tabular}{|l|r|r|}
\hline & \multicolumn{2}{|c|}{ Factor } \\
Component & $\begin{array}{c}1 \\
\text { Personal } \\
\text { Altruism }\end{array}$ & $\begin{array}{c}\text { Social/Instrumental } \\
\text { Norms }\end{array}$ \\
\hline personally believe in the cause & $\mathbf{. 7 3 2}$ & .046 \\
feel compassion to others & $\mathbf{. 6 5 0}$ & -.060 \\
you/someone you know has personally be affected & $\mathbf{. 5 9 5}$ & .132 \\
Gov gives credit on income taxes & -.128 & $\mathbf{. 6 9 9}$ \\
to fulfill religious obligations & .087 & $\mathbf{. 6 9 7}$ \\
owe something to the community & .386 & $\mathbf{. 5 2 3}$ \\
Variance Explained & $\mathbf{2 5 \%}$ & $\mathbf{2 1 \%}$ \\
\hline
\end{tabular}

Extraction Method: Principal Component Analysis. Rotation Method: Varimax with Kaiser Normalization. Rotation converged in 3 iterations. Total variance explained equals $46 \%$. 
Table II: Final Factor Pattern

Reasons for not Giving (More): Rotated Component Matrix

\begin{tabular}{|c|c|c|c|}
\hline & \multicolumn{3}{|c|}{ Factor } \\
\hline Component & $\begin{array}{c}1 \\
\text { Personal } \\
\text { Discontent }\end{array}$ & $\begin{array}{c}2 \\
\text { Competing } \\
\text { Demands } \\
\end{array}$ & $\begin{array}{c}3 \\
\text { Social } \\
\text { Barriers } \\
\end{array}$ \\
\hline already contributed enough & .709 & .049 & -.013 \\
\hline do not like the ways in which requests are made & .604 & .087 & .224 \\
\hline money will be used inefficiently & .584 & .128 & .335 \\
\hline volunteer instead of giving money & .557 & .088 & -.124 \\
\hline want to save money for future needs & 047 & .859 & .076 \\
\hline prefer to spend money in other ways & .192 & .815 & .056 \\
\hline don't know where to make a contribution & -.071 & -.027 & .803 \\
\hline hard to find a cause worth supporting & .198 & .156 & .669 \\
\hline Variance Explained & $20 \%$ & $18 \%$ & $16 \%$ \\
\hline
\end{tabular}

Extraction Method: Principal Component Analysis. Rotation Method: Varimax with Kaiser Normalization. Rotation converged in 5 iterations. Total variance explained equals 54\% 
Table III: Final Factor Pattern

Reasons for Volunteering: Rotated Component Matrix

\begin{tabular}{|c|c|c|c|}
\hline & \multicolumn{3}{|c|}{ Factor } \\
\hline Component & $\begin{array}{c}1 \\
\text { Personal } \\
\text { Benefits } \\
\end{array}$ & $\begin{array}{c}2 \\
\text { Personal } \\
\text { Altruism } \\
\end{array}$ & $\begin{array}{c}3 \\
\text { Social } \\
\text { Norms } \\
\end{array}$ \\
\hline to use your skills and experiences & .804 & .099 & -.053 \\
\hline to explore your own strengths & .772 & .153 & .094 \\
\hline $\begin{array}{l}\text { because you/someone you know has been } \\
\text { personally affected by the cause }\end{array}$ & .034 & .685 & -.005 \\
\hline to help a cause in which you personally believe & .047 & .676 & -.079 \\
\hline to fulfill religious obligations or beliefs & .106 & .512 & .081 \\
\hline because your friends volunteer & -.094 & .200 & .683 \\
\hline were you required by school, etc & -.038 & .061 & -.629 \\
\hline to improve you job opportunities & .424 & -.207 & .557 \\
\hline Variance Explained & $18 \%$ & $16 \%$ & $15 \%$ \\
\hline
\end{tabular}

Extraction Method: Principal Component Analysis. Rotation Method: Varimax with Kaiser Normalization. Rotation converged in 5 iterations. Total variance explained equals $49 \%$. 
Table IV: Final Factor Pattern

Reasons for not Volunteering (More): Rotated Component Matrix

\begin{tabular}{|c|c|c|c|c|}
\hline & \multicolumn{4}{|c|}{ Factor } \\
\hline Component & $\begin{array}{c}1 \\
\text { Time Demands }\end{array}$ & $\begin{array}{c}2 \\
\text { Personal } \\
\text { Costs } \\
\end{array}$ & $\begin{array}{c}3 \\
\text { Social } \\
\text { Barriers } \\
\end{array}$ & $\begin{array}{c}4 \\
\begin{array}{c}\text { Other Competing } \\
\text { Factors }\end{array} \\
\end{array}$ \\
\hline because you give money instead of time & .712 & .023 & -.002 & -.033 \\
\hline $\begin{array}{l}\text { because you are unwilling to make a year-round } \\
\text { commitment }\end{array}$ & .704 & .098 & .139 & -.137 \\
\hline because you have no interest & .624 & .087 & .101 & .127 \\
\hline because of concerns that you could be sued & -.001 & 680 & .157 & -.057 \\
\hline $\begin{array}{l}\text { because you were dissatisfied with a previous } \\
\text { volunteering experience }\end{array}$ & .149 & .600 & -.079 & .098 \\
\hline because of the financial cost of volunteering & .011 & .574 & .331 & -.003 \\
\hline $\begin{array}{l}\text { because you feel that you have already made your } \\
\text { contribution to volunteering }\end{array}$ & .265 & .405 & -.388 & .134 \\
\hline because you do not know how to get involved & .067 & .235 & .736 & .083 \\
\hline $\begin{array}{l}\text { because no one you know has personally asked } \\
\text { you }\end{array}$ & .252 & .030 & .733 & -.041 \\
\hline because you do not have any extra time & .110 & .152 & -.100 & -.806 \\
\hline $\begin{array}{l}\text { because you have health problems or are } \\
\text { physically unable }\end{array}$ & .079 & .227 & -.093 & .708 \\
\hline Variance Explained & $14 \%$ & $13 \%$ & $13 \%$ & $11 \%$ \\
\hline
\end{tabular}

Extraction Method: Principal Component Analysis. Rotation Method: Varimax with Kaiser Normalization. Rotation converged in 6 iterations. Total variance explained equals $52 \%$. 
Table V: Giving by Religious Affiliation

\begin{tabular}{|c|c|c|c|c|c|c|c|c|}
\hline $\begin{array}{c}\text { Giving } \\
(\% \text { of Total Sample) }\end{array}$ & $\begin{array}{c}\text { ConsProt } \\
8.6\end{array}$ & $\begin{array}{l}\text { LibProt } \\
17.5\end{array}$ & $\begin{array}{l}\mathrm{RC} \\
\mathbf{4 1 . 3}\end{array}$ & $\begin{array}{c}\text { OtherCath } \\
2.4\end{array}$ & $\begin{array}{c}\text { Jewish } \\
0.9\end{array}$ & $\begin{array}{c}\text { Eastern } \\
3.0\end{array}$ & $\begin{array}{c}\text { Other } \\
0.2\end{array}$ & $\begin{array}{c}\text { Non-Affil. } \\
26.1\end{array}$ \\
\hline $\begin{array}{l}\text { Total Dollar Amount } \\
(\$ C D N)\end{array}$ & $\$ 687$ & $\$ 284$ & $\$ 145$ & $\$ 163$ & $\$ 286$ & $\$ 188$ & $\$ 388$ & $\$ 105$ \\
\hline $\begin{array}{l}\% \text { of Total Household } \\
\text { Income }\end{array}$ & 1.4 & .61 & .32 & .41 & .45 & .45 & 1.7 & .19 \\
\hline $\begin{array}{l}\text { Total Dollar Amount to } \\
\text { Religion ( } \% \text { of Total) }\end{array}$ & $\begin{array}{c}\$ 516 \\
(75 \%) \\
\end{array}$ & $\begin{array}{c}\$ 134 \\
(47 \%)\end{array}$ & $\begin{array}{c}\$ 58 \\
(40 \%) \\
\end{array}$ & $\begin{array}{c}\$ 95 \\
(58 \%)\end{array}$ & $\begin{array}{c}\$ 81 \\
(28 \%) \\
\end{array}$ & $\begin{array}{c}\$ 135 \\
(72 \%) \\
\end{array}$ & $\begin{array}{c}\$ 129 \\
(33 \%) \\
\end{array}$ & $\begin{array}{c}\$ 9 \\
(8.5 \%) \\
\end{array}$ \\
\hline \multicolumn{9}{|l|}{$\begin{array}{l}\text { Ways of Giving } \\
(\% \text { who indicated })\end{array}$} \\
\hline Responding by Mail & 31 & 36 & 24 & 15 & 33 & 19 & 18 & 20 \\
\hline $\begin{array}{l}\text { Paying to Attend Charity } \\
\text { Event }\end{array}$ & 22 & 22 & 18 & 15 & 27 & 20 & 31 & 18 \\
\hline \multicolumn{9}{|l|}{ Using payroll Deductions } \\
\hline Sponsoring a Walk-a-thon & 46 & 54 & 31 & 28 & 46 & 22 & 41 & 39 \\
\hline In Memoriam & 19 & 32 & 18 & 15 & 40 & 13 & 16 & 15 \\
\hline $\begin{array}{l}\text { When Asked by Door-to- } \\
\text { Door Canvassing }\end{array}$ & 35 & 44 & 30 & 21 & 33 & 13 & 39 & 25 \\
\hline $\begin{array}{l}\text { When Asked by Someone } \\
\text { at a Shopping Centre }\end{array}$ & 22 & 23 & 24 & 20 & 17 & 11 & 52 & 19 \\
\hline $\begin{array}{l}\text { Through Collection at a } \\
\text { Church, Synagogue, etc }\end{array}$ & 57 & 37 & 38 & 40 & 29 & 47 & 32 & 6 \\
\hline
\end{tabular}


Table VI: Volunteering by Religious Affiliation

\begin{tabular}{|c|c|c|c|c|c|c|c|c|}
\hline Volunteering & ConsProt & LibProt & $\mathbf{R C}$ & OtherCath & Jewish & Eastern & Other & Non-Affil. \\
\hline $\begin{array}{l}\text { Total Average Annual } \\
\text { Hours Volunteered (Hrs) }\end{array}$ & 75 & 64 & 38 & 24 & 43 & 20 & 77 & 39 \\
\hline $\begin{array}{l}\% \text { of Total Available } \\
\text { Hours }\end{array}$ & $1.0474 \%$ & $0.8568 \%$ & $0.4939 \%$ & $0.3246 \%$ & $0.5645 \%$ & $0.2895 \%$ & $1.0368 \%$ & $0.5347 \%$ \\
\hline $\begin{array}{l}\text { Average Annual Hours } \\
\text { Volunteered to Religion } \\
\text { (\% of Total) }\end{array}$ & $\begin{array}{c}34.3 \\
(46 \%)\end{array}$ & $\begin{array}{c}10.4 \\
(16 \%)\end{array}$ & $\begin{array}{c}4.8 \\
(13 \%)\end{array}$ & $\begin{array}{c}2.5 \\
(10 \%)\end{array}$ & $\begin{array}{c}9.5 \\
(22 \%)\end{array}$ & $\begin{array}{c}6.3 \\
(32 \%)\end{array}$ & $\begin{array}{c}27.6 \\
(36 \%)\end{array}$ & $\begin{array}{c}.6 \\
(2 \%)\end{array}$ \\
\hline \multicolumn{9}{|l|}{$\begin{array}{l}\text { Ways of Volunteering } \\
\text { (\% who indicated })\end{array}$} \\
\hline $\begin{array}{l}\text { Canvassing, Campaigning, } \\
\text { or Fundraising }\end{array}$ & $16 \%$ & $17 \%$ & $9.1 \%$ & $7.6 \%$ & $8.1 \%$ & $7.6 \%$ & $21 \%$ & $10 \%$ \\
\hline $\begin{array}{l}\text { Serve as an unpaid } \\
\text { member of a board }\end{array}$ & $18 \%$ & $16 \%$ & $9.5 \%$ & $6.8 \%$ & $17 \%$ & $5.8 \%$ & $19 \%$ & $10 \%$ \\
\hline $\begin{array}{l}\text { Educate, influence public } \\
\text { opinion }\end{array}$ & $13 \%$ & $11 \%$ & $6.0 \%$ & $5.7 \%$ & $7.4 \%$ & $5.8 \%$ & $13 \%$ & $8.2 \%$ \\
\hline Help to organize activities & $25 \%$ & $20 \%$ & $13 \%$ & $12 \%$ & $14 \%$ & $11 \%$ & $30 \%$ & $15 \%$ \\
\hline $\begin{array}{l}\text { Consulting, executive, or } \\
\text { office work }\end{array}$ & $13 \%$ & $10 \%$ & $7.1 \%$ & $6.9 \%$ & $6.4 \%$ & $5.3 \%$ & $19 \%$ & $8.1 \%$ \\
\hline $\begin{array}{l}\text { Teach or coach for an } \\
\text { organization }\end{array}$ & $15 \%$ & $9.6 \%$ & $5.3 \%$ & $5.7 \%$ & $5.5 \%$ & $4.2 \%$ & $19 \%$ & $7.5 \%$ \\
\hline $\begin{array}{l}\text { Provide care or support, } \\
\text { including counselling }\end{array}$ & $16 \%$ & $9.3 \%$ & $6.2 \%$ & $4.8 \%$ & $9.6 \%$ & $4.3 \%$ & $26 \%$ & $5.2 \%$ \\
\hline $\begin{array}{l}\text { Collect, serve, or deliver } \\
\text { food or other goods }\end{array}$ & $13 \%$ & $9.0 \%$ & $6.0 \%$ & $7.1 \%$ & $12 \%$ & $4.6 \%$ & $12 \%$ & $4.7 \%$ \\
\hline Volunteer driving & $9.6 \%$ & $7.1 \%$ & $4.6 \%$ & $3.8 \%$ & $9.5 \%$ & $4.9 \%$ & $9.7 \%$ & $4.2 \%$ \\
\hline
\end{tabular}


Table VII: Reasons for Giving/Not Giving Mean Factor Scores by Religious Affiliation

\begin{tabular}{|l|c|c|c|c|c|c|c|c|}
\hline \multicolumn{1}{|c|}{ Factor } & ConsProt & LibProt & RC & OtherCath & Jewish & Eastern & Other & Non-Affil. \\
\hline Reasons for Giving & & & & & & & \\
\hline Personal Altruism & .13 & .20 & -.06 & -.27 & .15 & -.33 & .09 & -.04 \\
\hline Social/Instrumental Norms & .36 & .11 & -.01 & .09 & .35 & .56 & .15 & -.30 \\
\hline Reasons for Not Giving & & & & & & & \\
\hline Personal Discontent & .02 & .03 & .07 & -.05 & -.27 & -.09 & .12 & -.06 \\
\hline Competing Demands & -.08 & .01 & -.06 & -.03 & -.11 & -.0003 & -.49 & .10 \\
\hline Social Barriers & -.01 & -.09 & -.03 & .23 & -.15 & .62 & -.17 & .02 \\
\hline
\end{tabular}


Table VIII: Reasons for Volunteering/Not Volunteering Factor Scores by Religious Affiliation

\begin{tabular}{|c|c|c|c|c|c|c|c|c|}
\hline Factor & ConsProt & LibProt & $\mathbf{R C}$ & OtherCath & Jewish & Eastern & Other & Non-Affil. \\
\hline \multicolumn{9}{|c|}{ Reasons for Volunteering } \\
\hline Personal Benefits & .05 & .02 & -.05 & .22 & .30 & .16 & .07 & .01 \\
\hline Altruism & .35 & .22 & -.06 & .30 & .08 & .06 & .03 & -.32 \\
\hline Social Norms & -.03 & -.07 & -.001 & .06 & -.43 & .18 & -.33 & .08 \\
\hline \multicolumn{9}{|c|}{ Reasons for not Volunteering } \\
\hline Time Demands & -.09 & .02 & .04 & -.04 & .24 & .04 & -.33 & -.04 \\
\hline Personal Costs & -.02 & .02 & .03 & -.06 & -.15 & .09 & -.01 & -.02 \\
\hline Social Barriers & -.10 & -.16 & -.003 & .25 & .16 & .69 & .39 & .05 \\
\hline Competing Factors & -.04 & .10 & .02 & .05 & -.23 & -.04 & -.30 & -.11 \\
\hline
\end{tabular}


Table IX: Mediated Regression Analysis of Giving by Religious Affiliation

\begin{tabular}{|c|c|c|c|c|c|c|c|c|}
\hline & $\begin{array}{l}\text { Regression } 1 \\
\text { - Total } \\
\text { Giving }\end{array}$ & $\begin{array}{l}\text { Regression 2a - } \\
\text { Altruism }\end{array}$ & $\begin{array}{l}\text { Regression } \\
\text { 2b-Social } \\
\text { Norms }\end{array}$ & $\begin{array}{l}\text { Regression } \\
\text { 3a- } \\
\text { Discontent }\end{array}$ & $\begin{array}{l}\text { Regression } \\
\text { 3b - } \\
\text { Competing } \\
\text { Demands }\end{array}$ & $\begin{array}{l}\text { Regression } \\
\text { 3c-Social } \\
\text { Barriers }\end{array}$ & $\begin{array}{l}\text { Regression } \\
\text { 4a - Total } \\
\text { Giving, All } \\
\text { Mediators, } \\
\text { \& Total } \\
\text { income }\end{array}$ & $\begin{array}{l}\text { Regression } \\
\text { 4b - Total } \\
\text { Giving, All } \\
\text { Mediators, } \\
\text { Total } \\
\text { income, \& } \\
\text { Religiosity }\end{array}$ \\
\hline & $\operatorname{Beta}(\mathrm{t})$ & $\operatorname{Beta}(\mathrm{t})$ & $\operatorname{Beta}(\mathrm{t})$ & $\operatorname{Beta}(\mathrm{t})$ & $\operatorname{Beta}(\mathrm{t})$ & $\operatorname{Beta}(\mathrm{t})$ & $\operatorname{Beta}(\mathrm{t})$ & $\operatorname{Beta}(\mathrm{t})$ \\
\hline Constant & $105(422)$ & $-.04(-85)$ & $-.30(-632)$ & $-.06(-154)$ & $.10(240)$ & $.02(56)$ & $10(24)$ & $72(174)$ \\
\hline \multicolumn{9}{|l|}{$\begin{array}{l}\text { Religious } \\
\text { Affiliation: }\end{array}$} \\
\hline $\begin{array}{l}\text { Roman } \\
\text { Catholic }\end{array}$ & $.03(125)$ & $-.01(-35)$ & $.14(486)$ & $.07(250)$ & $-.08(-304)$ & $-.03(-103)$ & $.01(27)$ & $-.05(-158)$ \\
\hline Other Catholic & $.01(68)$ & $-.03(-138)$ & $.06(240)$ & $.002(9)$ & $-.02(-92)$ & $.03(143)$ & $.01(58)$ & $-.01(-33)$ \\
\hline $\begin{array}{l}\text { Liberal } \\
\text { Protestant }\end{array}$ & $.11(452)$ & $.10(341)$ & $.17(589)$ & $.04(139)$ & $-.03(-137)$ & $-.05(-179)$ & $.07(243)$ & $.03(99)$ \\
\hline $\begin{array}{l}\text { Conservative } \\
\text { Protestant }\end{array}$ & $.26(1161)$ & $.05(197)$ & $.20(745)$ & $.02(99)$ & $-.05(-218)$ & $-.01(-36)$ & $.24(913)$ & $.18(664)$ \\
\hline Jewish & $.03(129)$ & $.02(79)$ & $.06(270)$ & $-.02(-87)$ & $-.02(-89)$ & $-.02(-75)$ & $.01(32)$ & $-.002(-9)$ \\
\hline $\begin{array}{l}\text { Eastern } \\
\text { Religions }\end{array}$ & $.02(107)$ & $-.05(-197)$ & $.15(599)$ & $-.004(-19)$ & $-.02(-76)$ & $.10(450)$ & $.01(57)$ & $-.01(-42)$ \\
\hline $\begin{array}{l}\text { Other } \\
\text { Religions }\end{array}$ & $.02(108)$ & $.01(28)$ & $.02(100)$ & $.01(43)$ & $-.03(-136)$ & $-.01(-45)$ & $.02(92)$ & $.01(52)$ \\
\hline \multicolumn{9}{|l|}{ Mediators: } \\
\hline Altruism & & & & & & & $.05(216)$ & $.04(155)$ \\
\hline Social Norms & & & & & & & $.16(683)$ & $.13(530)$ \\
\hline Discontent & & & & & & & $-.01(-22)$ & $.002(9)$ \\
\hline $\begin{array}{l}\text { Competing } \\
\text { Demands }\end{array}$ & & & & & & & $-.04(-164)$ & $-.02(-101)$ \\
\hline Social Barriers & & & & & & & $-.06(-248)$ & $-.05(-229)$ \\
\hline Religiosity & & & & & & & & $.14(507)$ \\
\hline Total Income & & & & & & & $0.17(758)$ & $.18(783)$ \\
\hline $\mathbf{R}^{2}$ (Adjusted) & .065 & .017 & .047 & .004 & .005 & .004 & .126 & .139 \\
\hline
\end{tabular}


Table X: Mediated Regression Analysis of Volunteering by Religious Affiliation

\begin{tabular}{|c|c|c|c|c|c|c|c|c|c|c|}
\hline & $\begin{array}{l}\text { Regression } \\
1 \text { - Total } \\
\text { Hours }\end{array}$ & $\begin{array}{l}\text { Regression } \\
2 \mathbf{a}- \\
\text { Benefits }\end{array}$ & $\begin{array}{l}\text { Regression } \\
2 \mathrm{~b}- \\
\text { Altruism }\end{array}$ & $\begin{array}{l}\text { Regression } \\
\text { 2c-Social } \\
\text { Norms }\end{array}$ & $\begin{array}{l}\text { Regression } \\
\text { 3a - Time } \\
\text { Demands }\end{array}$ & $\begin{array}{l}\text { Regression } \\
\text { 3b-Costs }\end{array}$ & $\begin{array}{l}\text { Regression } \\
\text { 3c-Social } \\
\text { Barriers }\end{array}$ & $\begin{array}{l}\text { Regression } \\
\text { 3d - } \\
\text { Competing } \\
\text { Factors }\end{array}$ & $\begin{array}{l}\text { Regression } \\
4 a-\text { Total } \\
\text { Hours, All } \\
\text { Mediators, } \\
\& \\
\text { Available } \\
\text { Hours }\end{array}$ & $\begin{array}{l}\text { Regression } \\
\text { 4b - Total } \\
\text { Hours, All } \\
\text { Mediators, } \\
\text { Available } \\
\text { Hours \& } \\
\text { Religiosity }\end{array}$ \\
\hline & $\operatorname{Beta}(\mathrm{t})$ & $\operatorname{Beta}(\mathrm{t})$ & $\operatorname{Beta}(\mathrm{t})$ & $\operatorname{Beta}(\mathrm{t})$ & Beta(t) & $\operatorname{Beta}(\mathrm{t})$ & $\operatorname{Beta}(\mathrm{t})$ & $\operatorname{Beta}(\mathrm{t})$ & $\operatorname{Beta}(\mathrm{t})$ & Beta $(\mathrm{t})$ \\
\hline Constant & $39(567)$ & $.01(8)$ & $-.32(-401)$ & $.08(99)$ & $-.04(-99)$ & $-.02(-49)$ & $.05(122)$ & $-.11(-247)$ & $69(78)$ & $78(86)$ \\
\hline \multicolumn{11}{|l|}{$\begin{array}{l}\text { Religious } \\
\text { Affiliation: }\end{array}$} \\
\hline $\begin{array}{l}\text { Roman } \\
\text { Catholic }\end{array}$ & $-.003(-13)$ & $-.03(-54)$ & $.13(254)$ & $-.04(-77)$ & $.04(143)$ & $.02(86)$ & $-.03(-100)$ & $.06(226)$ & $-.003(-6)$ & $-.02(-28)$ \\
\hline Other Catholic & $-.01(-64)$ & $.03(67)$ & $.08(202)$ & $-.002(-6)$ & $.001(2)$ & $-.01(-22)$ & $.03(130)$ & $.03(105)$ & $-.02(-48)$ & $-.02(-55)$ \\
\hline $\begin{array}{l}\text { Liberal } \\
\text { Protestant }\end{array}$ & $.06(238)$ & $.01(14)$ & $.23(470)$ & $-.06(-129)$ & $.03(95)$ & $.02(62)$ & $-.08(-302)$ & $.08(294)$ & $.02(39)$ & $.01(82)$ \\
\hline $\begin{array}{l}\text { Conservative } \\
\text { Protestant }\end{array}$ & $.06(266)$ & $.01(28)$ & $.23(502)$ & $-.04(-83)$ & $-.01(-47)$ & $-.001(-3)$ & $-.04(-170)$ & $.02(83)$ & $-.004(-8)$ & $-.02(-33)$ \\
\hline Jewish & $.002(11)$ & $.03(62)$ & $.03(86)$ & $-.04(-108)$ & $.03(116)$ & $-.01(-53)$ & $.01(44)$ & $-.01(-51)$ & $.002(6)$ & $.00(1)$ \\
\hline $\begin{array}{l}\text { Eastern } \\
\text { Religions }\end{array}$ & $-.02(-86)$ & $.02(49)$ & $.05(125)$ & $.01(31)$ & $.02(64)$ & $.02(79)$ & $.11(465)$ & $.01(54)$ & $-.01(-27)$ & $-.02(-35)$ \\
\hline Other Religions & $.01(54)$ & $.004(10)$ & $.02(59)$ & $-.03(-69)$ & $-.02(-67)$ & $.00(2)$ & $.02(78)$ & $-.01(-43)$ & $-.01(-16)$ & $-.01(-22)$ \\
\hline \multicolumn{11}{|l|}{ Mediators: } \\
\hline Benefits & & & & & & & & & $.09(216)$ & $.09(214)$ \\
\hline Altruism & & & & & & & & & $.07(160)$ & $.06(146)$ \\
\hline Social Norms & & & & & & & & & $-.04(-103)$ & $-.04(-103)$ \\
\hline Time Demands & & & & & & & & & $-.11(-277)$ & $-.11(-273)$ \\
\hline Costs & & & & & & & & & $.05(109)$ & $.05(109)$ \\
\hline Social Barriers & & & & & & & & & $-.09(-207)$ & $-.08(-202)$ \\
\hline $\begin{array}{l}\text { Competing } \\
\text { Factors }\end{array}$ & & & & & & & & & $.03(80)$ & $.03(79)$ \\
\hline Religiosity & & & & & & & & & & $.03(57)$ \\
\hline & & & & & & & & & & \\
\hline Avail. Hrs. & & & & & & & & & $.04(89)$ & $.04(84)$ \\
\hline $\mathbf{R}^{2}$ (Adjusted) & .008 & .003 & .056 & .006 & .003 & .001 & .022 & .006 & .045 & .045 \\
\hline
\end{tabular}




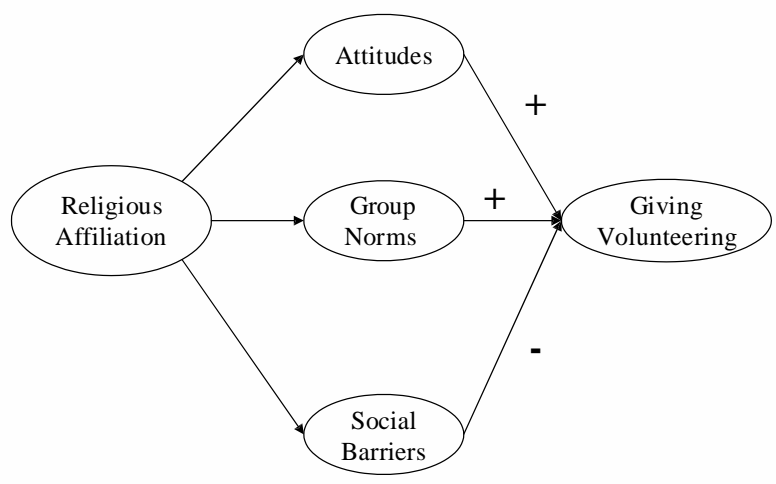

